\title{
81. Chromosome Studies in Ten Cases of Human Congenital Diseases*)
}

\author{
By Sajiro Makino, ${ }^{* *}$ Michihiro C. YoshIda, ${ }^{* *)}$ \\ and Muneo Mitani***) \\ (Comm. by Yoshimaro TANAKA, M.J.A., July 12, 1962)
}

Recent rather extensive chromosome studies in man have been directed towards the elucidation of the primary cellular event which causes clinical disorders or congenital syndromes. Cytogenetic investigations of patients with those defects and sexual anomalies are becoming increasingly important to clinicians by furnishing significant criteria for differential diagnosis of those defectives. In the laboratory of the senior author, a rather broad survey of human chromosomes has been in progress, carried on in conjunction with clinicians in pediatrics, urology and gynecology, with a hope to accumulate data from as many subjects as possible on a large scale, in order to provide information concerning the relationship of chromosomal variations to congenital and hereditary disorders, to various irregularities of sex development, as well as to neoplasia and to radiation exposure.

The present paper reports chromosome conditions in ten cases with clinical or congenital disorders comprising five cases of Down's syndromes generally referred to as mongolism, two cases of intersex, one each of megaloblastic anemia, hypothyroidism and amaurotic familial idiocy. Clinical diagnoses of each patient, together with sampling of the culture material for chromosome study, were made in the Department of Pediatrics, Sapporo Medical College, and in the Department of Urology, School of Medicine, Hokkaido University. All the cytological work was done in the Makino Laboratory, Hokkaido University. The diagnostic and clinical data of the patients dealt with in the present study are summarized in Table I.

Leukocytes were collected from peripheral blood of each patient and cultivated by means of a short-term culture method after Hungerford et al. (1959) (for detail, see Makino et al. $1962 \mathrm{a}, \mathrm{b}$, Makino and Kikuchi 1962). Chromosome counts and analyses were then made with those cells, based on slides prepared according to the water pretreatment acetic dahlia squash technique (Makino 1957).

*) Contribution No. 544 from the Zoological Institute, Faculty of Science, Hokkaido University, Sapporo.

**) Zoological Institute, Hokkaido University, Sapporo.

***) Department of Pediatrics, Sapporo Medical College, Sapporo. 
Table I. Diagnostic features of ten patients under study

\begin{tabular}{|c|c|c|c|c|}
\hline $\begin{array}{l}\text { Case } \\
\text { no. }\end{array}$ & Age and & $\operatorname{sex}$ & Diagnosis & Clinical findings \\
\hline 1 & $3 \mathrm{yrs}$ & $\hat{\circ}$ & $\begin{array}{l}\text { Down's } \\
\text { syndrome }\end{array}$ & $\begin{array}{l}\text { Typical facial configuration of Down's } \\
\text { syndrome, depressed nose bridge, epi- } \\
\text { canthus, a single transverse palmer } \\
\text { crease. }\end{array}$ \\
\hline 2 & $6 \mathrm{yrs}$ & $\hat{0}$ & $\begin{array}{l}\text { Down's } \\
\text { syndrome }\end{array}$ & $\begin{array}{l}\text { Typical facial configuration of Down's } \\
\text { syndrome, depressed nose bridge, epi- } \\
\text { canthus, rudimentary second phalange } \\
\text { of the 5th finger. }\end{array}$ \\
\hline 3 & $1 \mathrm{yr}$ & 우 & $\begin{array}{l}\text { Down's } \\
\text { syndrome }\end{array}$ & $\begin{array}{l}\text { Typical facial configuration of Down's } \\
\text { syndrome, depressed nose bridge, epi- } \\
\text { canthus, rudimentary second phalange } \\
\text { of the 5th finger. }\end{array}$ \\
\hline 4 & $4 \mathrm{yrs}$ & 오 & $\begin{array}{l}\text { Down's } \\
\text { syndrome }\end{array}$ & $\begin{array}{l}\text { Typical facial configuration of Down's } \\
\text { syndrome, depressed nose bridge, epi- } \\
\text { canthus. }\end{array}$ \\
\hline 5 & $1 \mathrm{yr}$ & 우 & $\begin{array}{l}\text { Down's } \\
\text { syndrome }\end{array}$ & $\begin{array}{l}\text { Typical facial configuration of Down's } \\
\text { syndrome, epicanthus, a single trans- } \\
\text { verse palmer crease, congenital heart } \\
\text { anomaly (ventricular septal defect?). }\end{array}$ \\
\hline 6 & $4 \mathrm{yrs}$ & - & Intersex & $\begin{array}{l}\text { Obesity, mental retardation, convulsion, } \\
\text { ataxia, small penis and scrotum and un- } \\
\text { descended testes. }\end{array}$ \\
\hline 7 & $28 \mathrm{yrs}$ & - & Intersex & $\begin{array}{l}\text { Very small-sized penis and histologically } \\
\text { atropic tests, hypogonadism. }\end{array}$ \\
\hline 8 & $2 \mathrm{yrs}$ & 우 & $\begin{array}{l}\text { Megaloblastic } \\
\text { anemia }\end{array}$ & $\begin{array}{l}\text { Probably corresponding to idiopathic } \\
\text { chronic megaloblastic anemia (Imerslund } \\
\text { 1960). Severe anemia, megaloblastic } \\
\text { type of erythropoiesis, albuminuria, } \\
\text { familial occurrence of similar defects. }\end{array}$ \\
\hline 9 & $8 \mathrm{~m}$ & $\hat{0}$ & Hypothyroidism & $\begin{array}{l}\text { Retardation of growth, mental sluggish- } \\
\text { ness, delayed bone age. }\end{array}$ \\
\hline 10 & $1 \mathrm{yr}$ & $\hat{0}$ & $\begin{array}{l}\text { Amaurotic } \\
\text { familial idiocy }\end{array}$ & $\begin{array}{l}\text { Blindness, motor weakness in all mus- } \\
\text { cles, a brown spot in area of fovea, } \\
\text { surrounded by a gray-white zone of } \\
\text { edematous retina, mental retardation. }\end{array}$ \\
\hline
\end{tabular}

Table II. Chromosome constitution in ten patients under study

\begin{tabular}{|c|c|c|c|c|c|c|c|c|c|}
\hline \multirow{2}{*}{$\begin{array}{l}\text { Case } \\
\text { no. }\end{array}$} & \multicolumn{6}{|c|}{ Distribution of chromosome counts } & \multirow{2}{*}{$\begin{array}{l}\text { Chromosome } \\
\text { constitution }\end{array}$} & \multirow{2}{*}{$\begin{array}{l}\text { No. of } \\
\text { cells anal. }\end{array}$} & \multirow{2}{*}{$\begin{array}{l}\text { No. of } \\
\text { cells obs. }\end{array}$} \\
\hline & 45 & 46 & 47 & 48 & $92 \quad 93$ & 94 & & & \\
\hline 1 & & & 17 & & & & 47 , trisomy 21 & 2 & 17 \\
\hline 2 & & & 5 & & & & "I & 0 & 5 \\
\hline 3 & & & 31 & & & 1 & "I & 3 & 32 \\
\hline 4 & & & 28 & & & & $\prime \prime$ & 2 & 28 \\
\hline 5 & & & 115 & & & & "I & 5 & 115 \\
\hline 6 & & 9 & & & & & $46, \mathrm{XY}$ & 2 & 9 \\
\hline 7 & & 20 & & & & & $46, \mathrm{XY}$ & 2 & 20 \\
\hline 8 & & 132 & & & 2 & & $46, \mathrm{XX}$ & 4 & 134 \\
\hline 9 & 1 & 23 & & 1 & 1 & & $46, \mathrm{XY}$ & 3 & 26 \\
\hline 10 & & 5 & & & & & $46, \mathrm{XY}$ & 2 & 5 \\
\hline
\end{tabular}


The five cases of Down's syndrome (mongolism) were three girls and two boys. On the basis of studies with leukocytes derived from each patient, they all showed consistent chromosome counts of 47 with a single tetraploid cell as an exception (Table II). Chromosome analyses made on 2 to 5 cells having 47 chromosomes from four cases have revealed that every cell possesses a normal complement of 46 chromosomes plus one extra element which is almost certainly identical to chromosome no. 21 in respect to size and shape (Figs. 1 and 2). Though one case (no. 2) was not subjected to chromosome analysis, it is most probable that this patient has an identical chromosome constitution on account of his chromosome count showing 47. It is then nearly certain that all the Down's syndrome cases here considered are 47 in chromosome number and trisomic for chromosome 21. Thus the present findings agree with regular Down's syndrome cases so far reported which show a chromosome count of 47 and trisomy of chromosome no. 21 .

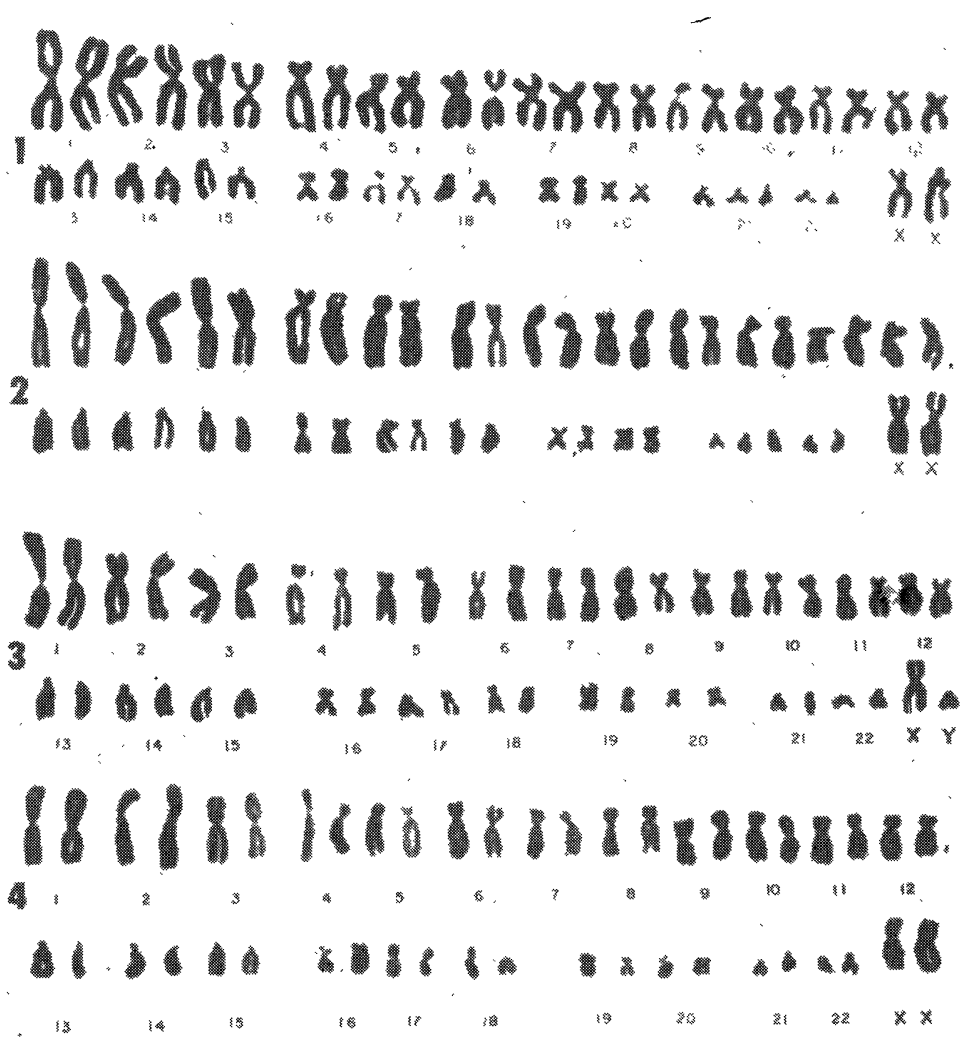

Figs. 1-4. Karyotype analyses based on leukocyte cultures from peripheral blood. 1, from a patient with Down's syndrome (no. 3). 2, from a patient with Down's syndrome (no. 4). 3, from an intersex individual (no. 7). 4, from a patient with megaloblastic anemia (no. 8). 
Examination of the chromosomes in two intersex cases under study yielded consistent counts of 46 chromosomes. Analysis of two cells in each showed that they had a normal chromosome complement consisting of 44 autosomes and an XY sex-constitution (Fig. 3). It is self-evident that those two intersexes are genetically male.

In the following three cases of congenital diseases, megaloblastic anemia, hypothyroidism and amaurotic familial idiocy, chromosomes were found to be consistently 46 in number. Karyotype analysis has proved that the chromosomes are normal both morphologically and numerically, since each patient possesses 44 autosomes of an apparently normal constitution and a sex chromosome complex made up of two X's in the female patient and $\mathrm{X}$ and $\mathrm{Y}$ in the two male ones (Fig. 4).

Remarks. Extensive application of newly developed cytogenetical methods to clinical disorders has led in recent years to the discovery of the significant relationship of chromosomal abnormalities to various sex anomalies and clinical or congenital deficiencies (for review, refer to Ford 1960, Böök 1961, Ferguson-Smith 1961, Harnden and Jacobs 1961, Miles 1961, Rappoport and Kaplan 1961, Sohval 1961). Five cases of Down's syndrome (mongolism) dealt with in the present study were found to have trisomy for the small satellited autosome, no. 21 , and 47 chromosomes. The majority of Down's syndrome so far cytologically studied were cases with 47 chromosomes and trisomy of the 21th chromosome. There are, however, several cases in which the trisomic 21 appeared attached to another autosome. It has generally been accepted that non-disjunction of a certain chromosome during meiosis is to be regarded as the most probable basis for the trisomy.

There have been reported many instances of congenital diseases in which no identifiable abnormality of chromosomes was demonstrated (Ferguson-Smith and Handmaker 1961, Makino and Kikuchi 1962, Makino et al. 1962 a, c, d). Three congenital defectives (megaloblastic anemia, hypothyroidism and amaurotic familial idiocy) as reported in this paper showed no chromosomal change from a normal human complement: they had 44 morphologically normal autosomes and a pair of sex-elements. It should be borne in mind that an identifiable chromosomal variation is not always associated with the etiological cause of human clinical disorders (Makino et al. 1962 a, c, d).

Cytological investigations of two intersex specimens showed that they were genetically males on account of their 46 chromosomes and an XY-sex constitution. An identical situation has been reported in several instances (see Harnden and Jacobs 1961, Makino et al. 1962 d). 
Increased studies on clinical or congenital abnormalities in relation to chromosome variation are now highly needed. Reliable survey work of this nature may produce great increase in knowledge of human cytogenetics.

In conclusion, ten cases of congenital syndromes subjected to cytological study are discussed in this paper. Five cases of Down's syndromes were found to be trisomic for chromosome no. 21 with a chromosome number of 47 , as widely known in this syndrome. Two cases of intersex individuals were diagnosed as being genetically of male sex. Three patients diagnosed as having congenital disorders were found to possess each a normal chromosome complement.

Kind co-operation given by Dr. K. Minamiura, Professor of Pediatrics, Sapporo Medical College, is gratefully acknowledged here.

\section{References}

Böök, J. A. (1961): De Genetica Medica, Part 3, 21-47.

Ferguson-Smith, M. A. (1961): Proc. Med. Genet., Chap. 8, 292-334.

Ferguson-Smith, M. A., and S. D. Handmaker (1961): Lancet, 1, 638-640.

Ford, C. E. (1960): Amer. J. Human Genet., 12, 104-117.

Harnden, D. G., and P. A. Jacobs (1961): Brit. Med. Bull., 17, 206-212.

Hungerford, D., A. J. Donnelly, P. C. Nowell, and S. Beck (1959): Amer. J. Human Genet., 11, 215-236.

Imerslund, O. (1960): Acta Paediat., 49, Suppl. 119, 1-115.

Makino, S. (1957): Intern. Rev. Cytol., 4, 25-84.

Makino, S., A., Tonomura, M. Mizutani, H. Sakakura, S. Kumakiri, S. Itoga, and M. Yamafuji (1962a): Proc. Japan Acad., 38, 31-36.

Makino, S., T. Honda, and M. Mitani (1962b): Proc. Japan Acad., 38, 47-51.

Makino, S., T. Honda, and T. Kajii (1962c): Proc. Japan Acad., 38, 52-56.

Makino, S., M. S. Sasaki, and T. Kajii (1962d): Proc. Japan Acad., 38, 166-170.

Makino, S. and Y. Kikuchi (1962): Proc. Japan Acad., 38, 124-128.

Miles, C. P. (1961): Stanford. Med. Bull., 19, 1-18.

Rappoport, S., and W. D. Kaplan (1961): J. Pediat., 59, 415-438.

Sohval, A. R. (1961): Am. J. Med., 31, 397-441. 